\title{
Hubungan Antara Hitung Jenis Leukosit dengan Derajat Penyakit Paru Obstruktif Kronik Berdasarkan Gejala Klinis dan Gold 2019 Pada Pasien Penyakit Paru Obstruktif Kronik Stabil di Rumah Sakit Islam Jakarta Sukapura
}

\author{
Nayla Sa'adah Alawiyah', Muhammad Fachri ${ }^{2}$ \\ 1) Program Studi Kedokteran, Fakultas Kedokteran dan Kesehatan, Universitas Muhammadiyah Jakarta \\ 2) Departemen Paru, Fakultas Kedokteran dan Kesehatan, Universitas Muhammadiyah Jakarta \\ *naylasaadah@yahoo.com
}

\begin{abstract}
Backgorund: Chronic Obstructive Pulmonary Disease (COPD) is an uncontagious disease that becomes one of the health problems in Indonesia, there is an estimated 4.8 million people with a prevalence of 56\%. Purposes: the purpose of this research is to know correlation of the differential blood count with chronic obstructive pulmonary disease degrees based on clinical symptoms and GOLD 2019 of stable COPD patients in Jakarta Islamic Hospital Sukapura period September 2018 - September 2019. Methods: this study is a quantitative research with the analytical descriptive method. The research design used is cross sectional. The sampling technique in this study is a total sampling technique. Amount of stable COPD patients studied as many as 35 patients. Symptoms assessment in COPD patients according to the Global Initiative for Chronic Obstructive Pulmonary Disease (GOLD) 2019 can use established a validated questionnaire that is COPD Assesment Test/CAT and Modified Medical Research Council/MMRC. Results: the result of the differential blood count most of them have normal eosinophil value, normal basophil value, the neutrophil value increases, the normal monocyte value, and normal lymphocytes value. Conclusion: the results showed a tendency to increase the value of leukocytes at each degree of COPD, but statistically there is no significant correlation of the differential blood count with chronic obstructive pulmonary disease degrees based on clinical symptoms and GOLD 2019 of stable COPD patients in RSIJ Sukapura.
\end{abstract}

Keywords: PPOK stable GOLD 2019, mMRC, CAT, Differential blood count.

\begin{abstract}
ABSTRAK
Latar belakang: Penyakit Paru Obstruktif Kronik (PPOK) merupakan penyakit tidak menular yang menjadi salah satu masalah kesehatan di Indonesia diperkirakan terdapat 4,8 juta orang dengan prevalensi 56\%. Tujuan: tujuan penelitian ini untuk mengetahui hubungan antara hitung jenis leukosit dengan derajat PPOK berdasarkan gejala klinis dan PPOK GOLD 2019 pada pasien PPOK stabil di Rumah Sakit Islam Jakarta Sukapura periode September 2018 September 2019. Metode: studi ini merupakan penelitian kuantitatif dengan metode deskriptif analitik. Desain penelitian yang digunakan yaitu cross sectional. Teknik pengambilan sampel dalam penelitian ini yaitu teknik total sampling. Jumlah pasien PPOK stabil yang diteliti sebanyak 35 pasien. Penilaian gejala pada pasien PPOK menurut Global Initiative for Chronic Obstructive Pulmonary Disease (GOLD) 2019 dapat menggunakan kuesioner yang sudah
\end{abstract}


divalidasi yaitu COPD Assesment Test/CAT dan Modified Medical Research Council/MMRC. Hasil: Hasil pemeriksaan hitung jenis leukosit terbanyak memiliki nilai eosinofil normal, nilai basofil normal, nilai neutrofil meningkat, nilai monosit normal, dan nilai limfosit normal. Kesimpulan: hasil penelitian menunjukkan kecenderungan peningkatan nilai leukosit pada setiap derajat PPOK, namun secara statistik tidak terdapat hubungan yang signifikan antara hitung jenis leukosit dengan derajat PPOK berdasarkan gejala klinis dan GOLD 2019 pada pasien PPOK stabil di RSIJ Sukapura.

Kata kunci: PPOK stabil, GOLD 2019, mMRC, CAT, hitung jenis leukosit.

\section{PENDAHULUAN}

Chronic Obstructive Pulmonary Disease (COPD) atau Penyakit Paru Obstruktif Kronik (PPOK) ialah penyakit tidak menular yang menjadi salah satu masalah kesehatan di Indonesia. PPOK merupakan penyakit pada system saluran napas yang dapat dicegah, diobati, serta ditandai dengan adanya keterbatasan aliran udara yang bersifat persisten dan progresif. Keterbatasan aliran udara diakibatkan karena terdapat penyempitan pada saluran napas kecil (obstruksi bronkiolitis) dan kerusakan parenkim (emfisema) (1).

Berdasarkan data Badan Kesehatan Dunia pada tahun 2002 PPOK menempati urutan ke-5 sebagai penyebab kematian di dunia dan diperkirakan pada tahun 2030 akan menempati urutan ke-3 sebagai penyebab kematian di seluruh dunia setelah penyakit kardiovaskuler dan kanker. Indonesia di perkirakan terdapat 4,8 juta orang yang menderita PPOK dengan prevalens $56 \%$, angka ini dapat terus meningkat dengan semakin banyaknya jumlah perokok karena $90 \%$ penderita PPOK adalah perokok atau mantan perokok (2). Menurut hasil Riset Kesehatan Dasar pada tahun 2013, terdapat $37 \%$ PPOK di Indonesia yang didapat berdasarkan hasil wawancara pada masyarakat usia 30 tahun keatas dengan jumlah prevalensi lebih tinggi pada laki-laki (3).
PPOK sering timbul pada usia pertengahan akibat kebiasaan merokok dalam jangka waktu lama. Jenis rokok dapat berisiko dengan abnormalitas fungsi paru, seperti yang terbukti pada penelitian Indonesia Pneumobile Project tahun 1989 bahwa perokok nonkretek berisiko 5 kali lebih tinggi sedangkan perokok kretek dapat berisiko 13 kali lebih tinggi terhadap terjadinya abnormalitas fungsi paru. Perokok pasif atau secondhand smoke juga memiliki risiko yang sama untuk terjadinya PPOK (2). Hubungan antara kebiasaan merokok dengan terjadinya PPOK merupakan hubungan dosis dengan respon, yaitu semakin banyak jumlah batang rokok yang dihisap dan semakin lama kebiasaan merokok maka akan semakin tinggi juga risiko menderita PPOK (4). Risiko terjadinya PPOK pada perokok bergantung pada dosis rokok yang dihisap, usia mulai merokok, jumlah batang rokok pertahun, dan lamanya merokok (2).

Gejala dan tanda PPOK sangat bervariasi, mulai dari yang ringan samapi berat. Diagnosis dipertimbangkan jika timbul tanda dan gejala yang sesuai dengan indikator dalam mendiagnosis PPOK seperti sesak, batuk kronik yang hilang timbul atau tidak berdahak, batuk kronik berdahak, riwayat terpajan faktor risiko, dan riwayat keluarga yang menderita PPOK (2). Penilaian gejala pada PPOK menurut Global Initiative for Chronic Pulmonary 
Disease 2019, dapat menggunakan kuesioner yang telah divalidasi yaitu $C O P D$ Assesment Test/CAT dan Modified Medical Research Council/MMRC, CAT merupakan kuesioner berisi 8 butir pertanyaan yang menggambarkan kualitas hidup penderita PPOK dan mempunyai rentang skor 0-40. mMRC merupakan alat yang digunakan untuk menilai derajat sesak napas pada penderita PPOK $(1,2)$.

Inflamasi saluran napas pada pasien PPOK merupakan respon inflamasi normal akibat iritasi kronik. Sel inflamasi pada PPOK ditandai dengan peningkatann jumlah sel CD8+/Limfosit Tc1, neutrofil, eosinofil, serta makrofag (2). Pada PPOK stabil ditandai dengan adanya ciri peradangan yang dominan yaitu banyaknya sel neutrofilik yang ditarik oleh interleukin 8, walaupun jumlah limfosit meningkat tetapi yang meningkat hanya sel T CD8 helper tipe 1 (5).

\section{METODE}

Studi ini merupakan penelitian kuantitatif dengan menggunakan metode deskriptif analitik. Desain penelitian yang digunakan yaitu cross sectional (potong lintang). Teknik pengambilan sampel dalam penelitian ini yaitu total sampling, Teknik Pengumpulan data didapatkankan dari data sekunder yang berasal dari rekam medis pada pasien PPOK stabil di Poli Paru Rumah Sakit Islam Jakarta Sukapura pada September 2018 - September 2019 yang meliputi hasil tes spirometri dan hitung jenis leukosit. Data primer yang didapat dari wawancara kuesioner mMRC dan CAT. Populasi yang digunakan yaitu seluruh pasien PPOK stabil yang berobat di Poli Paru Rumah Sakit Islam Jakarta Sukapura Periode September 2018 September 2019. Besar sampel diambil dengan cara mengumpulkan seluruh populasi yang telah memenuhi kriteria inklusi untuk dijadikan sampel dalam penelitian ini. Penelitian ini telah lulus kaji etik oleh Komisi Etik Penelitian Kesehatan Fakultas Kedokteran dan Kesehatan Universitas Muhammadiyah Jakarta Nomor: 117/PE/KE/FKK-UMJ/X/2019.

\section{HASIL}

Berdasarkan Tabel 1, menunjukkan karakteristik pasien PPOK stabil. Distribusi berdasarkan usia, didapatkan pasien terbanyak yaitu pada kelompok usia 60-69 tahun sebanyak 14 pasien $(40.0 \%)$ sedangkan pasien paling sedikit yaitu pada kelompok usia $>79$ tahun sebanyak 2 pasien $(5,7 \%)$. Distribusi berdasarkan jenis kelamin, didapatkan bahwa jumlah laki-laki sebanyak 31 pasien $(88.6 \%)$ dan perempuan sebanyak 4 pasien (11.4\%). Distribusi berdasarkan pendidikan, didapatkan bahwa pasien yang berpendidikan SMA sebanyak 14 orang (40.0\%) yang merupakan tingkat pendidikan terbanyak. Distribusi berdasarkan pekerjaan, didapatkan bahwa pegawai swasta merupakan pekerjaan terbanyak dengan jumlah 11 orang $(31.4 \%)$, kemudian diikuti dengan buruh 9 orang (25.7\%), pensiunan 6 orang (17.1\%), wiraswasta 4 orang $(11.4 \%)$, PNS 2 orang $(5.7 \%)$, tidak bekerja 2 orang $(5.7 \%)$, dan supir 1 orang $(2.9 \%)$.

Distribusi berdasarkan status merokok, didapatkan pasien yang merokok memiliki presentasi paling tinggi yaitu sebanyak 29 orang (82.9\%) sedangkan pasien yang tidak merokok sebanyak 6 orang $(17.1 \%)$. Distribusi berdasarkan indeks brinkman, pasien yang termasuk kriteria perokok sedang memiliki presentasi sebanyak 13 orang (37.1\%), perokok berat sebanyak 9 orang $(25.7 \%)$, perokok ringan 
sebanyak 9 orang (22.9\%), dan bukan perokok sebanyak 5 orang $(14,3 \%)$.

Tabel 1. Karakteristik Pasien PPOK Stabil yang Berobat di Poli Paru RSIJ Sukapura Periode September 2018 September 2019

\begin{tabular}{|c|c|c|}
\hline Karakteristik & $\mathbf{N}(35)$ & $\%$ \\
\hline \multicolumn{3}{|l|}{ Usia } \\
\hline$<40$ & 3 & 8.6 \\
\hline $40-49$ & 3 & 8.6 \\
\hline $50-59$ & 8 & 22.9 \\
\hline $60-69$ & 14 & 40.0 \\
\hline $70-79$ & 5 & 14.3 \\
\hline$>79$ & 2 & 5.7 \\
\hline \multicolumn{3}{|l|}{ Jenis Kelamin } \\
\hline Laki-laki & 31 & 88.6 \\
\hline Perempuan & 4 & 11.4 \\
\hline \multicolumn{3}{|l|}{ Pendidikan } \\
\hline Tidak sekolah & 1 & 2.9 \\
\hline SD & 6 & 17.1 \\
\hline SMP & 9 & 25.7 \\
\hline SMA & 14 & 40.0 \\
\hline Diploma & 0 & 0 \\
\hline Sarjana & 5 & 14.3 \\
\hline \multicolumn{3}{|l|}{ Pekerjaan } \\
\hline Tidak bekerja & 2 & 5.7 \\
\hline Pegawai Swasta & 11 & 31.4 \\
\hline PNS & 2 & 5.7 \\
\hline Wiraswasta & 4 & 11.4 \\
\hline Pensiunan & 6 & 17.1 \\
\hline Supir & 1 & 2.9 \\
\hline Buruh & 9 & 25.7 \\
\hline \multicolumn{3}{|l|}{ Status Merokok } \\
\hline Tidak Merokok & 6 & 17.1 \\
\hline Merokok & 29 & 82.9 \\
\hline \multicolumn{3}{|l|}{ Indeks Brinkman } \\
\hline Bukan perokok & 5 & 14.3 \\
\hline Perokok ringan & 8 & 22.9 \\
\hline Perokok sedang & 13 & 37.1 \\
\hline Perokok berat & 9 & 25.7 \\
\hline
\end{tabular}

Tabel 2. Distribusi Nilai Leukosit pada Pasien PPOK Stabil

\begin{tabular}{lcc}
\hline \multirow{2}{*}{ Nilai Leukosit } & \multicolumn{2}{c}{ Jumlah Pasien } \\
\cline { 2 - 3 } & $\mathrm{N}$ & $\%$ \\
\hline Menurun & 0 & 0 \\
Normal & 4 & 11.4 \\
Meningkat & 31 & 88.6 \\
Jumlah & 35 & 100.0 \\
\hline
\end{tabular}

Berdasarkan Tabel 2, terdapat 4 pasien (11.4\%) yang memiliki nilai leukosit normal, sedangkan yang memiliki nilai leukosit meningkat sebanyak 31 pasien $(88.6 \%)$.

Tabel 3. Distribusi Nilai Eosinofil pada Pasien PPOK Stabil

\begin{tabular}{lcc}
\hline \multirow{2}{*}{ Nilai Eosinofil } & \multicolumn{2}{c}{ Jumlah Pasien } \\
\cline { 2 - 3 } & $\mathrm{N}$ & $\%$ \\
\hline Menurun & 3 & 8.6 \\
Normal & 18 & 51.4 \\
Meningkat & 14 & 40.0 \\
Jumlah & 35 & 100.0 \\
\hline
\end{tabular}

Berdasarkan Tabel 3, terdapat 3 pasien memiliki nilai eosinofil menurun, 18 pasien (51.4\%) yang memiliki nilai eosinofil normal, dan 14 pasien $(40.0 \%)$ memiliki nilai eosinofil meningkat.

Tabel 4. Distribusi Nilai Basofil pada Pasien PPOK Stabil

\begin{tabular}{lcc}
\hline \multirow{2}{*}{ Nilai Basofil } & \multicolumn{2}{c}{ Jumlah Pasien } \\
\cline { 2 - 3 } & $\mathrm{N}$ & $\%$ \\
\hline Menurun & 0 & 0 \\
Normal & 34 & 97.1 \\
Meningkat & 1 & 2.9 \\
Jumlah & 35 & 100.0 \\
\hline
\end{tabular}

Berdasarkan Tabel 4, terdapat 34 pasien $(97.1 \%)$ yang memiliki nilai basofil normal, sedangkan yang memiliki nilai basofil meningkat sebanyak 1 pasien (2.9.6\%).

Tabel 5. Distribusi Nilai Neutrofil pada Pasien PPOK Stabil

\begin{tabular}{lcc}
\hline \multirow{2}{*}{ Nilai Neutrofil } & \multicolumn{2}{c}{ Jumlah Pasien } \\
\cline { 2 - 3 } & $\mathrm{N}$ & $\%$ \\
\hline Menurun & 2 & 5.7 \\
Normal & 10 & 28.6 \\
Meningkat & 23 & 65.7 \\
Jumlah & 35 & 100.0 \\
\hline
\end{tabular}


Berdasarkan Tabel 5, terdapat 2 pasien $(5.7 \%)$ yang memiliki nilai neutrofil menurun, 10 pasien $(28,6 \%)$ dengan nilai neutrofil normal dan yang memiliki nilai neutrofil meningkat sebanyak 23 pasien $(65,7 \%)$.

Tabel 6. Distribusi Nilai Monosit pada Pasien PPOK Stabil

\begin{tabular}{lcc}
\hline \multirow{2}{*}{ Nilai Monosit } & \multicolumn{2}{c}{ Jumlah Pasien } \\
\cline { 2 - 3 } & $\mathrm{N}$ & $\%$ \\
\hline Menurun & 0 & 0 \\
Normal & 18 & 51.4 \\
Meningkat & 17 & 48.6 \\
Jumlah & 35 & 100.0 \\
\hline
\end{tabular}

Berdasarkan Tabel 6, terdapat 18 pasien $(51.4 \%)$ yang memiliki nilai monosit normal, sedangkan yang memiliki nilai leukosit meningkat sebanyak 17 pasien (48.6\%).

Tabel 7. Distribusi Nilai Limfosit pada Pasien PPOK Stabil

\begin{tabular}{lcc}
\hline \multirow{2}{*}{ Nilai Limfosit } & \multicolumn{2}{c}{ Jumlah Pasien } \\
\cline { 2 - 3 } & $\mathrm{N}$ & $\%$ \\
\hline Menurun & 9 & 25.7 \\
Normal & 23 & 65.7 \\
Meningkat & 3 & 8.6 \\
Jumlah & 35 & 100.0 \\
\hline
\end{tabular}

Berdasarkan Tabel 7, terdapat 9 pasien $(25.7 \%)$ yang memiliki nilai limfosit menurun, 23 pasien $(65.7 \%)$ dengan nilai limfosit normal dan yang memiliki nilai limfosit meningkat sebanyak 3 pasien $(8.6 \%)$. 
Tabel 8. Hubungan Hitung Jenis Leukosit dengan Derajat PPOK Berdasarkan gejala klinis

Uji Chi-Square

\section{Leukosit}

Menurun

Normal

Meningkat

Eosinofil

Menurun

Normal

Meningkat

Basofil

Menurun

Normal

Meningkat

Neutrofil

Menurun

Normal

Meningkat

Monosit

Menurun

Normal

Meningkat

Limfosit

Menurun

Normal

Meningkat

PPOK Klinis

\begin{tabular}{ccccc}
\multicolumn{4}{c}{ PPOK Klinis } & \multirow{2}{*}{ P Value } \\
\cline { 1 - 3 } Kel A & Kel B & Kel C & Kel D & \\
\hline
\end{tabular}

$\begin{array}{lcll}0 & 0 & 0 & 0 \\ 3 & 1 & 0 & 0 \\ 7 & 11 & 6 & 7\end{array}$

0.158

7

(

6

0

6

$\begin{array}{ll}1 & 0 \\ 3 & 3 \\ 2 & 4\end{array}$

0.453

2

6

3

4

*Hubungan signifikan $(p$ value $<0.05)$ 
Tabel 9. Hubungan Hitung Jenis Leukosit dengan Derajat PPOK Berdasarkan GOLD 2019

Uji Chi-Square

\section{Leukosit}

Menurun

Normal

Meningkat

Eosinofil

Menurun

Normal

Meningkat

Basofil

Menurun

Normal

Meningkat

Neutrofil

Menurun

Normal

Meningkat

Monosit

Menurun

Normal

Meningkat

Limfosit

Menurun

Normal

Meningkat
PPOK GOLD 2019

GOLD I GOLD II GOLD III GOLD IV P Value

$\begin{array}{ccccc}0 & 0 & 0 & 0 & 0.028^{*} \\ 3 & 1 & 0 & 0 & \\ 4 & 10 & 11 & 6 & \end{array}$

*Hubungan signifikan $(p$ value $<0.05)$ 


\section{PEMBAHASAN}

\section{Karakteristik Pasien PPOK}

Hasil penelitian ini ditemukan bahwa kasus PPOK stabil terbanyak dalam kelompok usia 60-69 tahun yaitu dengan jumlah 14 orang (40\%). Hasil penelitian ini sesuai dengan penelitian di RSUD Aceh Tamiang yaitu pasien PPOK terbanyak pada kelompok umur >60 tahun (6).

Diketahui bahwa kasus PPOK stabil di Poli Paru RSIJ Sukapura mayoritas berjenis kelamin laki-laki dibandingkan perempuan yaitu dengan jumlah 31 pasien laki-laki $(88.6 \%)$ dan 4 pasien perempuan (11.4\%). Hasil penelitian yang dilakukan di RSUP H.Adam Malik Medan menyatakan bahwa mayoritas pasien PPOK sejumlah 95 orang $(86,4 \%)$ berjenis kelamin laki-laki dan 15 orang $(13,6 \%)$ berjenis kelamin perempuan (7).

Pada kategori pendidikan, ditemukan bahwa kasus PPOK lebih banyak pendidikannya SMA dengan jumlah 14 orang $(40.0 \%)$. Hasil penelitian ini sejalan dengan penlitian Rahmatika yang menyatakan pendidikan terbanyak penderita PPOK adalah SLTA yaitu 41 orang $(29,6 \%)$ dari 139 sampel $(6,8)$.

Pada kategori pekerjaan didapatkan pasien PPOK stabil mayoritas bekerja sebagai pegawai swasta dengan jumlah 11 pasien (31.4\%). Hasil penelitian ini cukup berbeda dengan penelitian Firdausi yang menunjukkan proporsi pekerjaan tertinggi adalah pensiunan yaitu sebanyak 13 orang, sedangkan pekerjaan terendah adalah buruh dan supir yaitu sebanyak 2 orang (9).

Status merokok pada pasien PPOK stabil di Poli Paru RSIJ Sukapura sebanyak 29 orang $(82.9 \%)$ merokok dan 6 orang (17.1\%) tidak merokok. Hasil ini sesuai dengan Rini Khairiani di RSUD dr.Soedarso Pontianak melaporkan dari 47 penderita sebanyak $43(91,49 \%)$ memiliki kebiasaan merokok (10).

Indeks brinkman pada pasien PPOK stabil di Poli Paru ESIJ Sukapura didapatkan mayoritas adalah perokok sedang yaitu sebanyak 13 orang $(37,1 \%)$. Penelitian ini sejalan dengan penelitian Muhammad Fachri dkk. yang melaporkan indeks brinkman pada pasien PPOK stabil umumnya ringan dan sedang (11).

\section{Gambaran Hitung Jenis Leukosit pada Pasien PPOK Stabil}

Nilai leukosit pada pasien PPOK stabil di Poli Paru RSIJ Sukapura mayoritas nilai leukositnya meningkat yaitu sebanyak 31 orang $(88.6 \%)$, hasil penelitian ini cukup sama dengan penelitian Nanang Hidayatulloh yang menjelaskan bahwa pada pemeriksaan penunjang hematologi rutin didapatkan leukositosis atau sel darah putih lebih dari batas normal (12).

Nilai eosinofil pada penelitian ini didapatkan kebanyakan nilai eosinofil normal dengan jumlah 18 orang (51.4\%), penelitian serupa melaporkan bahwa perokok yang menderita PPOK memiliki rerata hitung jenis basofil, eosinofil, neutrofil, limfosit, dan monosit yang normal (13).

Nilai basofil didapatkan paling banyak normal yaitu sebanyak 34 orang (97.1\%), sesuai dengan penelitian di RSUP Dr. M. Djamil Padang tentang hitung jenis leukosit pada pasien PPOK didapatkan bahwa nilai rata-rata hitung jenis basofil adalah normal (14).

Nilai neutrofil didapatkan rata-rata nilai neutrofil meningkat dengan jumlah 23 orang $(65.7 \%)$, penelitian ini sesuai dengan penelitian di RSUD Dr.Soetomo bahwa pasien PPOK didapatkan peningkatan jumlah neutrofil yang berhubungan dengan tingkat keparahan penyakit PPOK (15). 
Nilai monosit didapatkan sebanyak 18 orang yang nilai monositnya normal (51.4\%), sesuai dengan penelitian Martanya didapatkan pada pasien PPOK tanpa penyakit penyerta diperoleh nilai monosit adalah normal (14).

Nilai limfosit pada pasien PPOK stabil di Poli Paru RSIJ Sukapura didapatkan 23 orang $(65.7 \%)$ nilai limfositnya normal, hasil penelitian ini berbeda dengan penelitian di RSUP Dr. M. Djamil Padang didapatkan hitung jenis leukosit pada Pasien PPOK yaitu nilai limfosit menurun (14).

\section{Hubungan Hitung Jenis Leukosit dengan Derajat PPOK}

Dalam penelitian ini didapatkan kecenderungan peningkatan nilai leukosit pada setiap derajat PPOK, namun secara statistik tidak terdapat hubungan yang signifikan antara nilai leukosit dengan derajat PPOK berdasarkan gejala klinis ( $P$ value $=0,158)$ dan didapatkan hubungan antara nilai leukosit dengan derajat PPOK berdasarkan GOLD 2019 ( $P$ value = 0,028). Peningkatan nilai leukosit pada pasien PPOK kemungkinan disebabkan karena kebiasaan merokok kronik yang dapat meningkatkan jumlah leukosit (16).

Didapatkan nilai eosinofil mayoritas normal, namun secara statistik belum bermakna atau tidak terdapat hubungan yang signifikan antara nilai eosinofil dengan derajat PPOK berdasarkan gejala klinis $(P$ value $=0,453)$ dan GOLD $2019(P$ value $=0,393)$. Penelitian di RSUP Dr. M. Djamil Padang diketahui bahwa nilai eosinofil normal ${ }^{14}$ dan didukung juga oleh penelitian Barnes PJ yang menyebutkan juga bahwa eosinofil pada pasien PPOK normal dibandingkan dengan pasien asthma (17).
Kategori nilai basofil, pada penelitian ini ditemukan data terbanyak adalah nilai basofil yang normal pada setiap derajat PPOK, namun secara statistik tidak terdapat hubungan yang signifikan antara nilai basofil dengan derajat PPOK berdasarkan gejala klinis $(P$ value $=0,578)$ dan GOLD $2019(P$ value $=0,523)$. Hasil penelitian ini sesuai dengan hasil penelitian yang mejelaskan bahwa rata-rata nilai basofil normal yaitu baik pada pasien PPOK tanpa penyakit penyerta, dengan penyakit penyerta infeksi, ataupun dengan penyakit penyerta non infeksi (14).

Terdapat kecenderungan peningkatan nilai neutrofil pada setiap derajat PPOK, namun secara statistik tidak terdapat hubungan yang signifikan antara nilai neutrofil dengan derajat PPOK berdasarkan gejala klinis $(P$ value $=0,249)$ dan GOLD $2019(P$ value $=0,079)$. Sesuai dengan penelitian Martantya RS dkk. yang mendapatkan niali neutrofil meningkat, peningkatan hitung jenis neutrofil PPOK dapat diakibatkan sebagai respon terhadap inflamasi kronik pada patogenesis PPOK dan dapat disebabkan juga karena penyakit penyerta infeksi yang diderita pasien (14).

Kategori nilai monosit, pada penelitian ini didapatkan nilai monosit terbanyak yaitu nilai monosit normal pada masing-masing derajat PPOK, secara statistik terdapat hubungan antara nilai monosit dengan derajat PPOK berdasarkan gejala klinis $(P$ value $=0,049)$ sedangkan tidak terdapat hubungan yang signifikan antara nilai monosit dengan derajat PPOK berdasarkan GOLD 2019 ( $P$ value = 0,696). Hasil penelitian ini sesuai dengan hasil penelitian terdahulu yang menjelaskan bahwa rata-rata nilai monosit yaitu normal pada pasien PPOK (14). 
Didapatkan bahwa nilai limfosit terbanyak pada pasien PPOK stabil di RSIJ Sukapura yaitu nilai limfositnya normal, seeara statistik terdapat hubungan antara nilai limfosit dengan derajat PPOK berdasarkan gejala klinis $(P$ value $=0,013)$ sedangkan tidak terdapat hubungan yang signifikan antara nilai limfosit dengan derajat PPOK berdasarkan GOLD 2019 ( $P$ value $=0,491)$. Berbeda dengan penelitian di RSUP Dr. M. Djamil padang ditemukan bahwa gambaran hitung jenis leukosit pada pasien PPOK memperlihatkan nilai limfosit menurun (14), perbedaan hasil yang terjadi dapat juga dikarenakan oleh sampel penelitian yang sedikit yaitu berjumlah 35 pasien sehingga data yang didapat kurang bervariasi.

\section{KESIMPULAN}

Penelitian dilakukan kepada 35 pasien PPOK Stabil yang berobat di Poli Paru RSIJ Sukapura terbanyak berusia 60-69 tahun dan terbanyak berjenis kelamin laki-laki. Tingkat pendidikan akhir pada pasien PPOK stabil yang terbanyak adalah Sekolah Menengah Atas (SMA). Pekerjaan pada pasien PPOK stabil terbanyak adalah pegawai swasta. Status merokok pada pasien PPOK stabil yaitu sebanyak 29 pasien $(82.9 \%)$ merokok, dengan indeks brinkman terbanyak yaitu perokok sedang.

Pravalensi nilai mMRC grade 0 lebih banyak yaitu 14 pasien. Prevalensi CAT $>10$ lebih banyak yaitu 20 pasien. Hasil pemeriksaan hitung jenis leukosit pada pasien PPOK stabil di Poli Paru RSIJ Sukapura terbanyak memiliki nilai leukosit meningkat, nilai eosinofil normal, nilai basofil normal, nilai neutrofil meningkat, nilai monosit normal, dan nilai limfosit normal.

Derajat PPOK berdasarkan gejala klinis terbanyak yaitu kelompok B sebanyak 12 pasien, sedangkan derajat PPOK berdasarkan GOLD 2019 terbanyak adalah GOLD II dan III yang masingmasing sebanyak 11 pasien.

Pasien PPOK stabil berdasarkan gejala klinis pada hitung jenis leukosit didapatkan kecenderungan peningkatan nilai neutrofil pada masing-masing derajat, namun secara statistik belum bermakna.

Pasien PPOK stabil berdasarkan GOLD 2019 pada hitung jenis leukosit didapatkan kecenderungan peningkatan nilai neutrofil pada masing-masing derajat, namun secara statistik belum bermakna.

Disarankan untuk melakukan pemeriksaan penunjang yang dapat membantu penegakan diagnosis dan dapat menambah kelengkapan status rakam medic. Disarankan pada pengambilan sampel berdasarkan data primer (kuesioner) dapat dibantu oleh dokter untuk memberi informasi kepada pasien karena tidak semua pasien bersedia untuk ditanya yang berhubungan dengan penyakitnya. Disarankan untuk peneliti selanjutnya agar mengambil sampel yang lebih banyak. Disarankan untuk peneliti selanjutnya agar melakukan perbandingan hitung jenis leukosit pada kelompok PPOK dan non PPOK.

\section{UCAPAN TERIMAKASIH}

Dengan selesainya penelitian ini, saya mengucapkan terimakasih banyak kepada semua pihak yang telah berkontribusi dalam penelitian ini sehingga penelitian ini dapat terlaksana dengan baik dan lancar.

\section{KONFLIK KEPENTINGAN}

Pada penelitian ini, tidak terdapat konflik kepentingan dan tidak ada koneksi dengan organisasi tertentu yang dapat menimbulkan pertanyaan atau bias pada hasil penelitian. 


\section{REFERENSI}

1. Global Strategy for Diagnosis Management and Prevention of Chronic Obstuctive Pulmonary Disease. Global Initiative for Chronic Obstructive Lung Disease. Med Com Res. 2019.

2. Perhimpunan Dokter Paru Indonesia. Pedoman Diagnosis dan Penatalaksanaan PPOK. Perhimpunan Dokter Paru Indonesia. Universitas Indonesia Press; 2016. $1-4,9,17,25,107,108 \mathrm{p}$.

3. Badan Penelitian dan Pengembangan Kesehatan. Riset Kesehatan Dasar 2013. 2013.

4. Forey BA, Thornton AJ, Lee PN. Systematic review with metaanalysis of the epidemiological evidence relating smoking to COPD, chronic bronchitis and emphysema. BMC Pulm Med. 2011;11:164-79.

5. Darmanto D. Respirologi (Respiratory Medicine). Edisi 2. Jakarta: EGC; 2014. 114-118 p.

6. Anita R. Karakteristik penderita penyakit paru obstruksi kronik yang di rawat inap di RSUD Aceh Tamiang tahun 2007-2008. Universitas Sumatera Utara; 2009.

7. Sidabutar P, Rasmaliah, Hiswani. Karakteristik penderita penyakit paru obstruktif kronik yang di rawat inap di RSUP $\mathrm{H}$. Adam Malik Medan tahun 2012. Universitas Sumatera Utara; 2012.

8. Naser F, Medison I, Erly. Gambaran Derajat Merokok Pada Penderita PPOK di Bagian Paru RSUP Dr. M. Djamil. J Kesehat Andalas. 2016;5(2):306-11.

9. Firdausi. Hubungan Derajat Obstruksi Paru dengan Kualitas Hidup Penderita PPOK Di RSUD DR. Soedarso Pontianak. Universitas Tanjungpura; 2014.

10. Khairani R. Pola Distribusi Penyakit Paru Obstruktif Kronik Berdasarkan Usia, Jenis Kelamin dan Perilaku Merokok di RSU dr.Soedarso
Pontianak Periode Februari - Juni 2009. 2010.

11. Fachri M, Yunus F, Wiyono WH, Kekalih A. Perbandingan Nilai Hormon Testosteron dan Growth Hormone pada Berbagai Derajat Penyakit Paru Obstruktif Kronik Stabil. J Respir Indo. 2012;32(4):208-17.

12. Hidayatulloh N. Acute Exacerbations on Chronic Ostructive Pulmonary Disease ( Copd ) With Secondary Infection. J Agromed Unila. 2015;2(1):57-62.

13. Rumora L, Milevoj L, Popović-Grle S, Barišić K, Grubišić TŽ, Čepelak I. Reduction in peripheral blood leukocyte heat shock proteins 27 and 70 expression in chronic obstructive pulmonary disease. Croat Chem Acta. 2008;81(1):73-80.

14. Martantya RS, Nasrul E, Basyar M. Gambaran Hitung Jenis Leukosit pada Pasien Penyakit Paru Obstruktif Kronik yang Dirawat di RSUP Dr. M. Djamil Padang. J Kesehat Andalas. 2014;3(2):217-20.

15. Yudhawati R, Prasetiyo YD. Imunopatogenesis Penyakit Paru Obstruktif Kronik. J Respirasi. 2019;4(1):19.

16. van Eeden S F, Sin D D. Chronic Obstructive Pulmonary Disease: A Chronic Systemic Inflammatory Disease. Respiration. 2008;75:22438.

17. Barnes PJ. Similarities and differences in inflammatory mechanisms of asthma and COPD. Breathe. 2011;7(3):229-38. 